\title{
Phase and chemical composition analysis of pigments used in Cucuteni Neolithic painted ceramics
}

\author{
Bogdan Constantinescu', Roxana Bugoi', Emmanuel Pantos ${ }^{2}$, Dragomir Popovici3 \\ 1 'Horia Hulubei' National Institute of Nuclear Physics and Engineering, Bucharest, Romania \\ bconst@nipne.ro \\ 2 CCLRC, Daresbury Laboratory, Warrington, UK \\ 3 National Museum of Romania's History, Bucharest, Romania
}

\begin{abstract}
Two analytical methods - 241Am-based X-Ray Fluorescence (XRF) and Synchrotron Radiation X-ray Diffraction (SR-XRD) - were used to investigate the elemental and mineralogical composition of pigments which decorate some Cucuteni Neolithic ceramic sherds. Local hematite and local calcite were the main components for red and white pigments, respectively. For black pigments, iron oxides (e.g. magnetite) were used. They were often mixed with manganese oxides (e.g. jacobsite), which originated from Iacobeni manganese minerals deposits on the Bistrita River. Taking into account the results of the experiments, several conclusions regarding manufacturing procedures employed, and potential trade routes during the Neolithic were drawn.
\end{abstract}

IZVLEČEK - Za določanje elementarne in mineraloške sestave pigmentov, s katerimi so okrašene nekatere keramične posode kulture Cucuteni, sta bili uporabljeni dve analitski metodi - 241 Am X-Ray Fluorescence (XRF) in Synchrotron Radiation X-ray Diffraction (SR-XRD). Lokalni hematit in kalcit sta bila glavni komponenti rdečih oziroma belih pigmentov. Za črne pigmente so uporabljali železove okside (magnetit). Pogosto so jih zmešali z manganovimi oksidi (jakobsitom), ki izvirajo iz Iacobeni manganovih mineralnih depozitov reke Bistrita. Če upoštevamo rezultate poizkusov, lahko potegnemo več zaključkov o uporabljenih proizvodnih postopkih in o možnih trgovskih poteh v času neolitika.

KEY WORDS - Cucuteni-Tripolye; ceramics; pigments; XRF; SR-XRD

\section{Cucuteni ceramics}

The history of the V-IVth millennia BCE is marked by the flourishing of some great Eneolithical civilizations in the South-Eastern part of Europe: Vinča, Gumelniţa and Cucuteni-Tripolye, representing moments of high cultural evolution. Spread over a vast territory, with a total area of more than $300000 \mathrm{~km}^{2}$ in Romania, the Republic of Moldova and Ukraine, the Cucuteni (in Romania, Tripolye in Ukraine) culture is one of the last brilliant cultural expressions of the Copper Age. Cucuteni-Tripolye culture had a long evolution, being divided by specialists into three main phases: Cucuteni A, Cucuteni A-B and Cucuteni $\mathrm{B}$. The skilful and ingenious use of all the natural resources allowed the Cucutenian communities to build solid and lasting houses, with resistant wooden structures covered with clay mixed with straw and hay. The craftsmen manufactured tools in either carved or polished stone (flint, opal, jasper, etc.), bone, horn or metal (copper), thus showing a high level of knowledge.

The 'Queen' of prehistoric pottery, the Cucutenian ceramics (Figs. 1, 2,3) represent the most eloquent proof not only of a perfect mastery of pottery (production and temperature control and clay modelling), but also of an extremely well-developed aesthetic sense that gave birth to genuine and unrivalled prehistoric masterpieces. The decorations on this pottery is proof of a remarkable aesthetic sense and, at the same time, of a very complex spiritual life. The prehistoric craftsmen created characteristic decorations for each of the three evolutional stages of the 
culture, with the use of incised lines, flutings and colours (white, black and red), using the spiral as an essential decorative element on the external (and sometimes, internal) surface of the pots. It is almost certain that the colours had magical significance: red $=$ life (blood), white $=$ the good (light), and black $=$ the evil (darkness).

In the following lines, the previous results obtained on Cucuteni ceramics by using X-Ray Fluorescence (XRF), X-Ray Diffraction (XRD), and other specific mineralogical methods will be reviewed. By means of the XRF and powder diffraction analysis of a number of Cucuteni sherds from the Poduri settlement (Bacău district - $50 \mathrm{~km}$ East of the Bistriţa River) were analyzed by Niculescu and Coltos (Niculescu, Coltos and Popovici 1982.205-206). They pointed out that the chromatophorous minerals of the white, red and dark brown pigments were calcium silicate, hematite, and jacobsite respectively, confirming the results obtained for other Cucuteni-Tripolye settlements by Stos-Gale and Rook (1981.155-161).

In a synthetic study of Cucuteni-Tripolye culture, Ellis (1980.211-230) made a technological characterization of the Cucutenian pottery. The X-ray diffraction and microscopic analyses were aimed at determining the mineralogical components of the ceramic composition, and the pigments used in the painting of the pottery. The results showed that the sources of clay were local; the black pigment came from manganese ores in the region, the red pigment from the alteration of the iron minerals, and the white from marls and kaolins. In late Cucuteni culture was fired

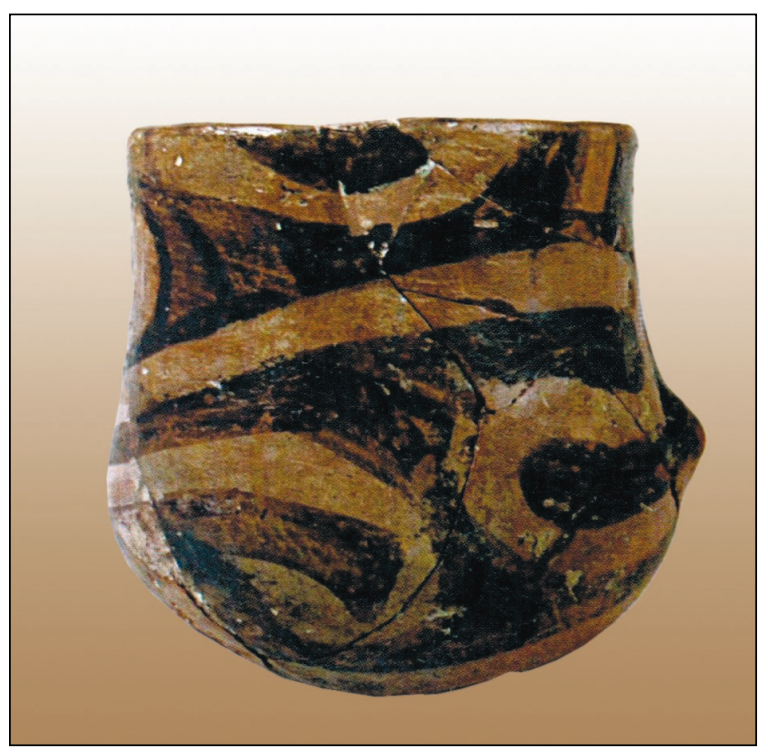

Fig. 2. Cucuteni A pottery, excavated from Poduri site.

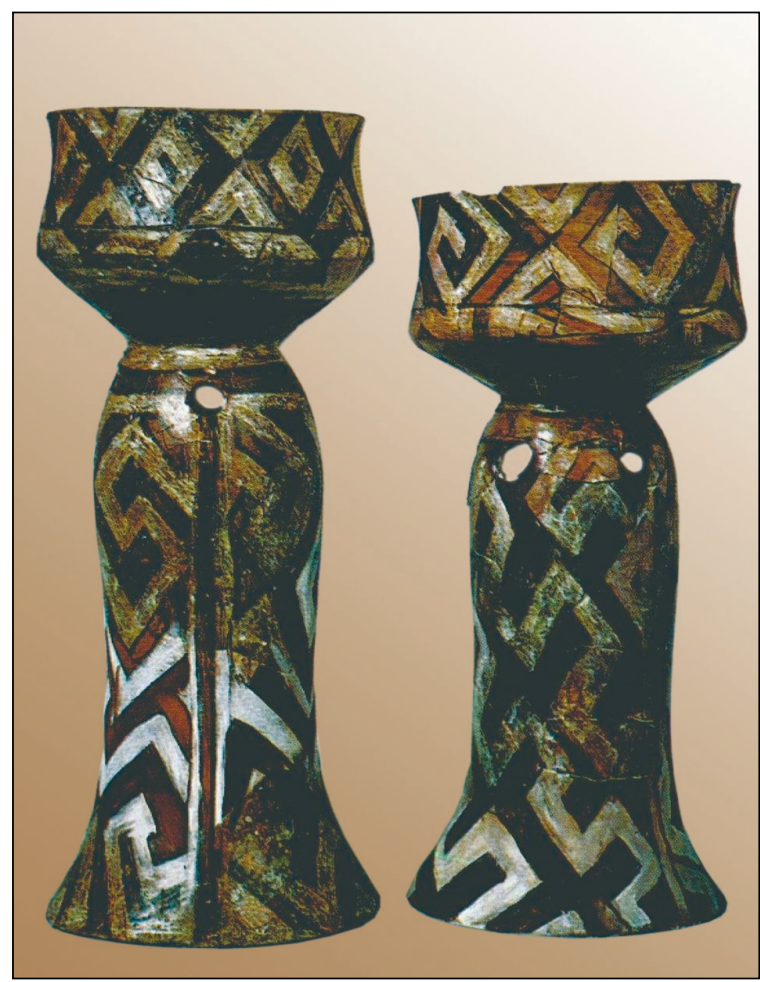

Fig. 1. Cucuteni A pottery, excavated from Poduri site.

in kilns with a controlled atmosphere, the temperatures in the kilns reaching $1000-1100{ }^{\circ} \mathrm{C}$.

A comprehensive study of Cucuteni ceramics from Northern Moldova (including pigments issue) has been made by Gâț̆ă in (Marinescu-Bâlcu and Bolomey 2000.111-131).

Summarizing the results from all the above references, it can be stated that the pigments used for the Cucuteni ceramics painting were mineral pigments including clay minerals, quartz, and feldspars, without iron and manganese oxides for the white chro-

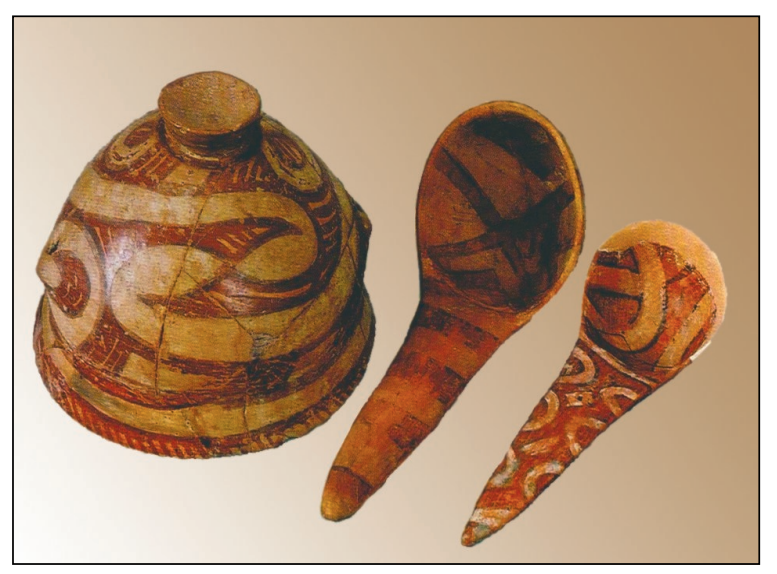

Fig. 3. Cucuteni A pottery (Romanian National History Museum). 
mes, with iron oxides for the red chromes, and with manganese oxides for the brownish-black chromes. These pigments were prepared starting from different coloured clays as raw materials by powdering, dispersion in water, separation of the fine fraction by decantation, and drying. In general, the pigment particle dimensions were of 5-15 $\mu \mathrm{m}$, based on the width at half intensity of the quartz line at $4.26 \AA$ (Sherrer's law). The raw materials were cements and concretions with manganese oxides (birnesite and manganite - very often found in Iacobeni deposits) for the brownish-black chromes, iron and manganese concretions, cambic horizons or lehms (goethite $-\alpha$-FOOH brown-red-brown-yellow colour and lepidocrocite) for the red chromes, and a loam without iron and manganese oxides for the white chrome. Through firing, the iron oxides, goethite and lepidocrocite, were transformed into hematite $\left(\mathrm{Fe}_{2} \mathrm{O}_{3}-\right.$ reddish-grey-white colour) for the red chromes, the manganese oxides, birnesite and manganite, into bixbyite, and more rarely into jacobsite, depending on the iron and manganese content, and rarely into haussmanite. The firing of the clay minerals caused the predominant components to transform into oxides in the process of crystallization, and at a temperature of over $900^{\circ} \mathrm{C}, \gamma \mathrm{Al}_{2} \mathrm{O}_{3}$ appeared. The fineness of the pigment particles and their mineralogical composition indicate that the raw material for the pigments came from the proximity of the settlement, or from the region. The experimental preparation of pigments with brownish black and red chrome from cemented sand, iron and manganese concretions, and reddish clays, and the similar composition, chromes and fineness thus obtained proved that these were the sources for pigments.

White pigment was prepared from loam deprived of chromophorous oxides; analyses of white and of its sources were identical when the former had not undergone firing.

The firm adhesion of the pigments to the vessel walls was explained by their smectite content, a clay mineral that gives the required adhesion. Neither the clay, nor the pigments had calcareous concretions or noticeable amounts of carbonates dispersed in the fabric, and their source appeared to be a layer leached of carbonates. The grain conglomerate structure of the medium and course fabric, the large amounts of iron and manganese concretions and broken sherds in the ceramic mass, and the presence of remains from pigment preparation, indicated their employment as an admixture in the fabric of vessels with thicker walls.
Regarding the technological aspects of ceramics production, the pottery was fired in an oxidizing atmosphere, in kilns with a combustion chamber and firing chamber separated by a perforated grate. All Cucuteni ceramics in the settlement were invariably fired according to an imported program. When the temperature rose too quickly to the nominal firing temperature during the initial stage, fissures and firing cracks appeared in the ceramic mass. The continuous firing stage was thoroughly maintained at a nominal temperature of $800-900^{\circ} \mathrm{C}$, which could be assessed by the uniform and complete firing of most vessels. A slow cooling stage followed, lasting at least half a day, with draught reduced to a minimum, allowing the complete transformation of $\beta$ quartz into $\alpha$ quartz. The hue of the brownish-black pigment, whose colour was rendered especially by manganese hydroxides (possibly birnesite and manganite), became more intense by firing, due to the formation of bixbyite in most of the cases, of jacobsite more rarely, and of hausmanite accidentally, according to the content of iron and manganese oxides and the firing temperature. Lepidocrocite and goethite in the red pigments always turned into hematite. Clay minerals in the white pigment were dehydroxylated, and the formation of $\gamma \mathrm{Al}_{2} \mathrm{O}_{3}$ occurred exclusively in the fragments fired at a temperature above $900^{\circ} \mathrm{C}$.

\section{Experimental}

For this study, two analytical methods were used: ${ }^{241} \mathrm{Am}$ based XRF and powder SR-XRD. The analyzed ceramics sherds were selected from the collection of the National Museum of Romanian History in Bucharest.

$\mathrm{XRF}$ is an analytical method used for the determination of elemental composition. It consists of the detection of the characteristic X-ray emitted by the analyzed object as a consequence of its bombardment with photons of suitable energy (tens of $\mathrm{keV}$ at most). The analytical method is sensitive (minimum detection limits in the order of parts per million - ppm), fast, and, most important when dealing with archaeological artefacts, non-destructive.

For the XRF measurements performed in this study, a spectrometer consisting of a $30 \mathrm{mCi}{ }^{241} \mathrm{Am}$ annular gamma-source and a $\mathrm{Si}(\mathrm{Li})$ detector $(180 \mathrm{eV}$ FWHM at $5.9 \mathrm{keV}$ resolution) was used. The elemental intensities data were normalized to their total background spectrum counts - the sum of all characteristic X-rays intensities for the excitation source - 
respectively, and subtracted from their corresponding normalized paste composition. Due to the pigments layers strong non-homogeneity and to avoid difficult calibration procedures, only the ratios of the main characteristic elements were used.

$\mathrm{XRD}$ is capable of providing qualitative and sometimes quantitative information on regarding the phases (e.g. compounds) composition. The analytical method is based on the fact that the wavelengths of X-rays are of the same order of magnitude as the distances between atoms or ions in a molecule or crystal $\left(\sim 1 \AA=10^{-10} \mathrm{~m}\right)$. Therefore, a crystal - or a crystalline powder - diffracts an X-ray beam passing through it, producing beams at specific angles depending on the X-ray wavelength, the crystal orientation, and the structure of the crystal. By analyzing the resulting diffraction pattern, information on the phases present in the analyzed sample are obtained. However, XRD is a destructive method, a certain amount of sample (e.g. crystalline powder) being necessary for the analysis, the measurements taking place in transmission mode.

Using conventional XRD in pottery analysis, major phases can be identified. However, in the case of archaeological objects, when the amount of sample to be analyzed has to be as small as possible, it is necessary to use the best experimental facilities. The advent of synchrotron radiation sources promoted the method of Synchrotron Radiation-X Ray Diffraction (SR-XRD), which became a powerful tool for detailed structural determination and mineral phase studies (Uda 2000.758-761). Its success is due to the fact that minute amounts of sample can be analyzed in a very short time (Tang 2001.1015-1024).

In particular, this experiment was focused on finding the composition of the pigments used to decorate some Cucuteni ceramics sherds. As special case is the one of the black pigments, the main candidates belong to three categories: graphite, manganese minerals and/or iron compounds. From previous analyses reported in Dumitrescu (1985) it is known that for Gumelniţa (3500-2500 BC) culture, graphite, and for Petreşti (3500-2500 BC) culture magnetite were used.

The SR-XRD measurements were performed at two locations: at the Synchrotron Radiation Source (SRS), Daresbury Laboratory (DL), UK, and at MAX-lab, Lund, Sweden. Some of the SR-XRD data were taken at station 14.1 of the SRS, by employing X-ray of $1.488 \AA$ wavelength, $0.2 \times 0.2 \mathrm{~mm}$ beam size and a flux of 1013 photons/s. The detection of the diffraction pattern was performed using a Quantum 4 ADSC CCD detector, which collects two-dimensional diffraction patterns of $2304 \times 2304$ pixels. The measurements were performed in transmission mode with an acquisition time of 30 seconds.

The pigment powders were gently scratched from some tens of ceramics sherds using a diamond file. The pigments were taken from areas of different colours (white, red and brown/black), as well as from the clay. Clay powders from all the sherds were also measured in order to compare any contribution in the diffraction patterns of the pigments, taking into account the fact that the painted layers were very thin (tens of $\mu \mathrm{m}$ ), and it was likely to have some powder from the ceramic body in the sample extracted from the decorated surface.

At DL the powders were put in a sample cassette having 36 holes, each of them having as a backing Scotch tape $₫$. The powders were pressed onto the Scotch tape and the excess powder was removed in order to have only a thin layer of it on the tape. The overall acquisition time per sample was minimized by the fact the cassette position (i.e. from a hole to the neighboring one) was moved under computer control from outside the station hutch. Silicon powder was used as a standard mineral phase, in order to determine the distance between sample and detector and the centre of the diffraction pattern - both required in order to reduce the data to intensity versus $2 \theta$ angle graphs for further analysis.

The data reduction was performed by using the FIT2D package (the integration of the diffraction rings). The mineral phase identification was carried out with the aid of the ICDD (International Centre for Diffraction Data) ®/JCPDS (Joint Committee for Powder Diffraction Studies) database, as well as the search-match procedures using the X'Pert HighScore Plus and XPLOT software available at DL. The tape background has been subtracted for all the spectra using X'Pert HighScore Plus software.

The MAX II measurements were performed at beam line 7.11 using the Huber G670 imaging-plate Guiner camera (Ståhl 2000.394-390) installed on crystallgraphy beamline I711 at the MAX II synchrotron, Lund, Sweden (Cerenius et al. 2000.203-208). The samples - powder on Scotch tape - were exposed for $1200 \mathrm{~s}$ each to synchrotron radiation of $1.364 \AA \mathrm{wa}$ velength. 
The analysis of the experimental data began with the identification of the relevant pigments using the Diffrac Plus data base of mineralogical compounds at MAX II. Further analysis consisted of the construction of the diffraction pattern using the data base information, followed by comparison with the results obtained from measurements after background subtraction.

SR-XRD was used as a very accurate method to distinguish different clays and mineral pigments of various Neolithic pottery-producing centers located on Romanian territory, most of them belonging to $\mathrm{Cu}-$ cuteni-Tripolye painted Neolithic ceramics.

Ceramics sherds belonging to the following cultures: Criş-Starčevo (6000-4500 BC), the oldest Neolithical culture, which covered the whole Balkan Peninsula and Carpathian Basin, Vinča (4200-3500 BC), Tiszapolgar (4500-3500 BC), Petreşti (3500-2500 BC), Gumelniţa (3500-2500 BC), with its most spectacular archaeological site: the golden cemetery at Varna, were also studied. The extension of the study to other cultures was due to the fact that the type and quantity of clay minerals and non-plastic inclusions in the clay can vary from region to region and the composition can be altered by the preparation procedure and manufacturing process.

\section{Results}

Painted (red-white-brown-black) Cucuteni sherds (Cucuteni A period) found in Moldova in sites situated in Bistriţa Valley down the river (Izvoare, Calu, Caşăria, Ghelăiești) were analyzed.

The XRF measurements revealed that for the black (dark brown or chocolate black) colour Mn and Fe were the main elements (see Fig. 4). For provenance studies, the $\mathrm{Mn} / \mathrm{Fe}$ ratio is significant because, due to the very close energy values of the X-rays emitted from both atoms, the matrix effects due to the presence of major (and lighter) elements can be assumed to have the same effect on the numerator and denominator. Three groups of sherds were found: $\mathrm{Mn} / \mathrm{Fe}=1 / 20,1 / 5,1 / 3(1 / 20$ is a normal value for a common soil). In the area of Cucuteni culture there are two main Mn deposits: Iacobeni, up to the Bistriţa River $150 \mathrm{~km}$ north of our analyzed sites in Moldova, where the $\mathrm{Mn} / \mathrm{Fe}$ ratio is under 3/10; and Krivoi Rog (Nikolaev) on the Dnepr River in Ukraine, where the $\mathrm{Mn} / \mathrm{Fe}$ ratio is from $8 / 10$ up to $10 / 10$. The results obtained strongly suggest the use of Iacobeni Mn minerals.

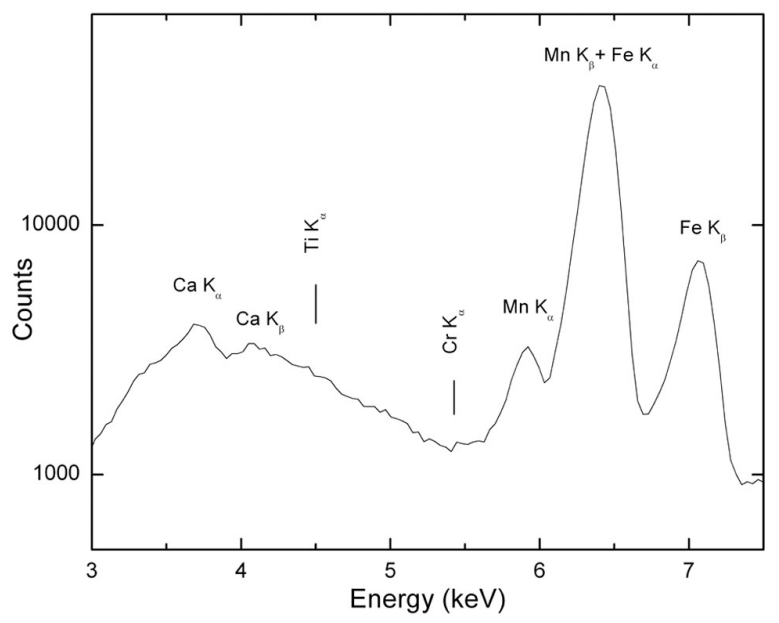

Fig. 4. Cucuteni black pigment XRF spectrum.

Concerning the white colour, $\mathrm{Ca}$ is the main element, the pigment raw material being a light clay (type kaolin) found relatively frequently in the region.

For the red colour we found Fe and Ti, concluding that the pigment is an iron-rich, clay-based one, with Ti used as reinforcing agent.

The analyzed clay was found to be of local provenances, with great variation in composition (e.g. a lot of $\mathrm{Ca}$ for the central region of Transylvania, a lot of Fe for Moldova and Banat, a lot of $\mathrm{K}$ in the NorthEast Transylvania). No clue regarding possible commercial exchanges was obtained from taking into account these results. When the black colour was close to dark brown, the compositional studies revealed Fe oxides in its content. Indications of the use of carbon from bones (Central Transylvania), but also from graphite (Gumelniţa culture), in which connections with the Neolithic graphite mines in North-East Bulgaria were revealed. The most interesting case is the site from Criş-Starčevo situated in Oltenia (Sălcuța), where Mn was detected as pyrolusite. This mineral was abundant in the North of Greece and largely used in the $4^{\text {th }}-5^{\text {th }}$ centuries $\mathrm{BC}$ to produce the famous Attic black glass sherds. A possible commercial connection South-North in the Balkan Peninsula can thus be deduced. In order to confirm this hypothesis, other Neolithic sites in the area of the Carpathian Mountains- Danube ceramics have to be analyzed.

Regarding the SR-XRD data obtained at DL, UK, the diffraction pattern analysis led to the following conclusions:

- In some of the sherds with black decoration that showed the presence of Mn in XRF spectra, several 
varieties of jacobsite $\left(\mathrm{Fe}_{2} \mathrm{MnO}_{4}\right)$ from the ICDD database fit the position and relative intensity of five of the peaks reasonably well. On the basis of the XRF data that showed a clear presence of Mn in these two samples, it was concluded that jacobsite is present in the black colour decoration of these samples, but with a slightly modified chemical formula where $\mathrm{Fe}$ and $\mathrm{Mn}$ are reduced in weight due to the presence of other metal atoms, such as $\mathrm{Mg}$, that alter the crystal lattice slightly. Magnesian jacobsite showed the best fit for the position and relative intensity of the peaks in the data (see Fig. 5).

- In other sherds, the brown/black colour was due to the presence of magnetite (iron oxide $\mathrm{Fe}_{3} \mathrm{O}^{4}$ ).

- A considerable amount of time was spent trying to identify black pigment patterns other than jacobsite, such as graphite, and other Fe and Mn compounds, such as hausmannite, pyrite, pyrolusite, bixbyite, pyroxmangite, manganite, despujolsite, and rhodonite. Graphite is hard to resolve in the acquired diffraction patterns, since it exhibits a strong overlap at $3.4 \AA$ with the quartz peak, which is situated at $3.34 \AA$; however, since the other peaks of graphite were not found in the black pigment diffraction patterns, the hypothesis of using carbon based pigments can not be supported. None of the above mentioned Fe and Mn minerals were found in any of the black pigment samples.

- Although the white colour was explained by the previous measurements on similar sherds as resulting either from calcite, kaolinite or from gypsum, the present data led to the conclusion that only in one of the sherds was some calcite found, as well as some augite (see Fig. 6).

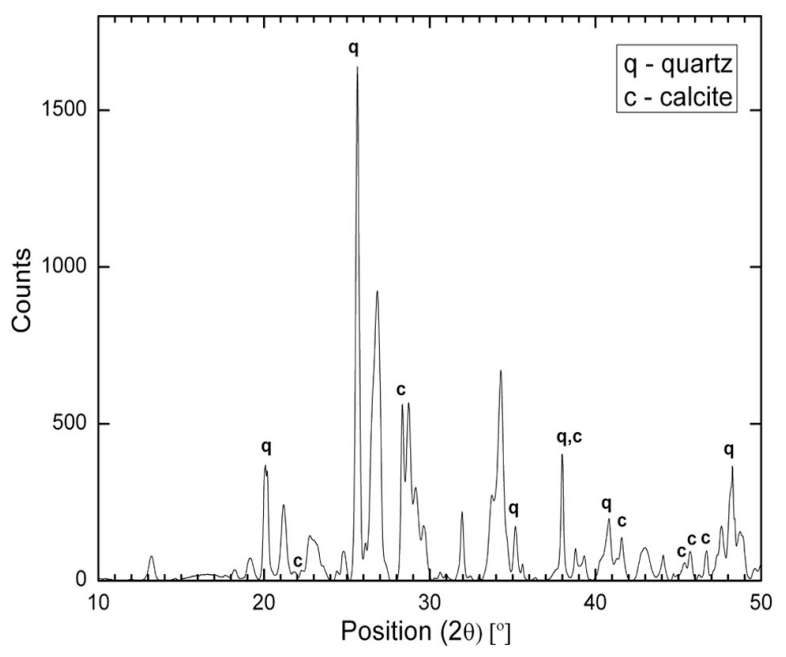

Fig. 6. Cucuteni white pigment SR-XRD spectrum.

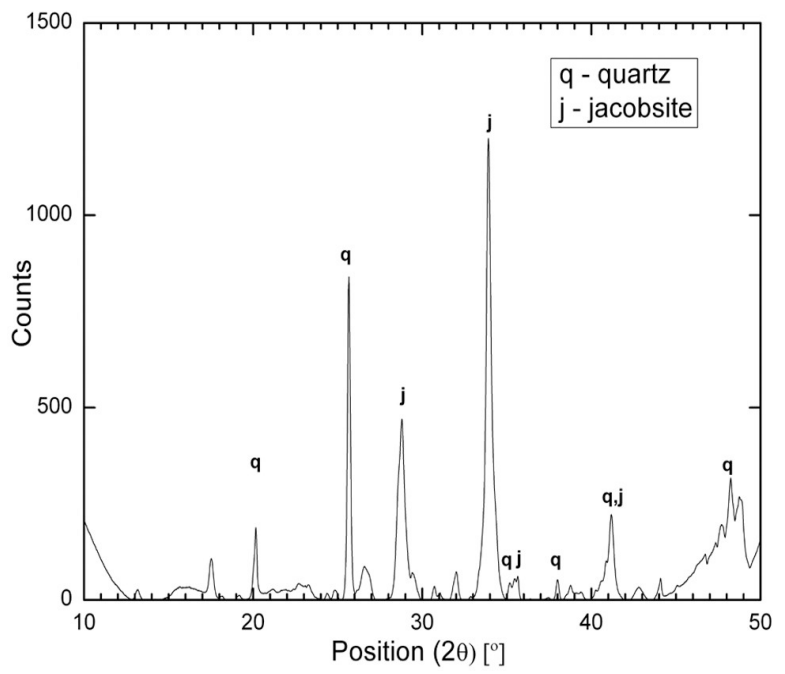

Fig. 5. Cucuteni black pigment SR-XRD spectrum.

- The red colour seems to come from the higher content in hematite of the powder (see Fig. 7). Hematite also seems to be a component of the corresponding ceramic body, but in much smaller amounts.

- The ceramic body samples contain silicates, diopside being identifying as a well matching phase in most of the samples.

The SR-XRD data obtained in Lund, Sweden, led to the clear identification of the black pigment composition from Cucuteni in Northern Moldavia and Ariuşd in South-Eastern Transylvania type pottery (6th$4^{\text {th }}$ millennia $\mathrm{BC}$ ): pyroxmangite (rodonite), an iron manganese silicate $\left(\mathrm{Fe}^{2+}, \mathrm{Mn}^{2+} \cdot \mathrm{CaMn}_{4}\left[\mathrm{Si}_{5} \mathrm{O}_{15}\right]\right)$ for high-temperature, $\geq 600^{\circ} \mathrm{C}$, fired pottery (the advanced Cucuteni ceramics types $\mathrm{A}$ and $\mathrm{B}$ ), and a mixture of goethite $(\alpha \mathrm{FeO}-\mathrm{OH})$, haussmanite $\left(\mathrm{MnMn}_{2} \mathrm{O}_{4}\right)$, jacobsite $\left(\mathrm{Fe}_{2} \mathrm{MnO}_{4}\right)$, bixbyite $(\mathrm{Mn}, \mathrm{Fe})_{2} \mathrm{O}_{3}$ and psilomelane $\left(\mathrm{MnO}+\mathrm{MnO}_{2}+\mathrm{H}_{2} \mathrm{O}\right.$ in variable proportions) for

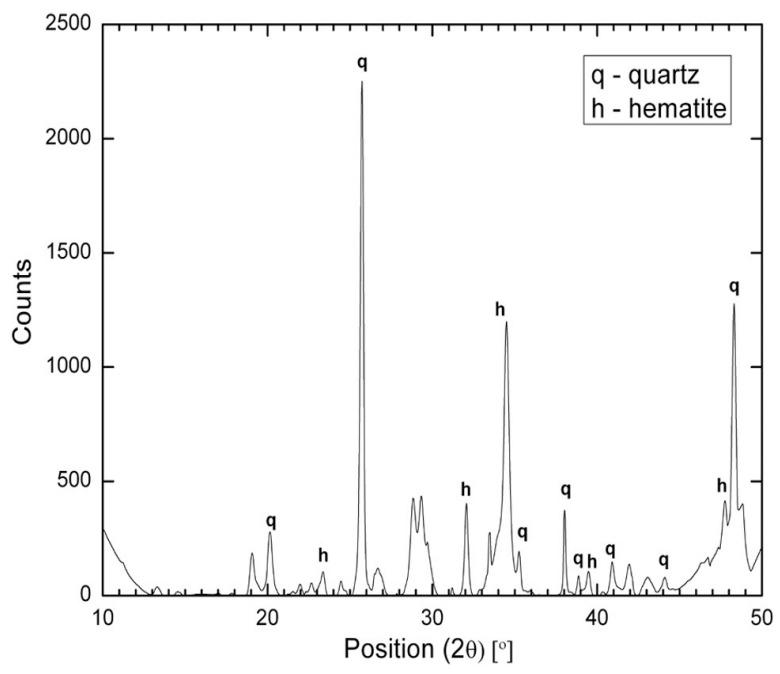

Fig. 7. Cucuteni red pigment SR-XRD spectrum. 
pottery fired at low temperature $\left(\leq 400{ }^{\circ} \mathrm{C}\right)$ (the primitive pre-Cucuteni type $\mathrm{C}$ ).

Historically, all these minerals have their origin in the North Moldavian mineral deposits of Iacobeni, leading to the conclusion that Neolithic trade routes already existed, covering approximately $500 \mathrm{~km}$ with the crossing of the Carpathians along the Bistrita River. In the same samples there was no evidence of pyrolusite $\left(\mathrm{MnO}_{2}\right)$ and manganite $[\mathrm{MnO}(\mathrm{OH})]$, the main components of Ukrainian Nikopol manganese deposit (used as black pigment source by contemporary Tripolye Neolithic culture). Other important results were the identification of magnetite (iron oxide $\left.\mathrm{Fe}_{3} \mathrm{O}_{4}\right)$ as the main component for the black pigments of the Central Transylvania Petressti culture (4200-3500 BC), and the identification of graphite as black pigment for Oltenia Starčevo-Cris culture ceramics (6th $-5^{\text {th }}$ millennia $\mathrm{BC}$ ), most probably from Northern Bulgaria graphite deposits. Finally, the black color of some carbon-based pigments is due to their organic origin (bone or wood) and it was quite challenging to identify them for several Cucuteni sherds from North-Eastern Moldavia.

We can suppose that the transportation from Iacobeni downriver of the Mn and Fe containing clays used as raw materials for pigments was done by raft (navigation on rafts made of conifers logs tied together using plant fibre ropes). In this area, rafting is a traditional means of transporting timber (wood used in carpentry and in house building), mentioned in documents as early as the $14^{\text {th }}$ century.

The white pigment composition appears as a combination of calcite $\left(\mathrm{CaCO}_{3}\right)$ for Cucuteni culture and as calcium silicates mixed with aluminum silicate-illite $\left.\left\{\left(\mathrm{K}, \mathrm{H}_{2}\right)\right) \mathrm{Al}_{2}\left[\left(\mathrm{H}_{2} \mathrm{O}, \mathrm{OH}\right)_{2}\right] \mathrm{AlSi}_{3} \mathrm{O}_{10}\right\}$ for Petreşti culture (Transylvania). As expected, the measurements have shown the presence of hematite (iron oxide $\mathrm{Fe}_{2} \mathrm{O}_{3}$ ) as the main component for red pigments for all the sherds examined. The clay examined for all the sherds was identified as of local provenance. It can be stated that the pigments used for the examined Neolithic ceramics painted sherds were mineral pig- ments including clay minerals, quartz and feldspars, with manganese oxides for the brownish-black chromes, with iron oxides for the red chromes, and without iron or manganese oxides for the white chromes. Through firing, the manganese oxides were transformed into bixbyite, and more rarely into jacobsite, depending on the iron and manganese content, and rarely into haussmanite at temperatures less than $400^{\circ} \mathrm{C}$, and into piroxmangite at temperatures higher than $600^{\circ} \mathrm{C}$. Correspondingly, the iron oxides were transformed into hematite for the red chromes.

\section{Conclusions}

The conclusion of this study is that the pigments used to decorate Cucuteni Neolithic ceramics were mainly based on iron oxides for the red hues, and calcium silicate and calcium carbonate for the white, while the black pigment was due to different iron and manganese compounds, such as magnetite and jacobsite. It is obvious that during this Neolithic period pottery workshops extended greatly over the present Romanian territory, local clays being mostly used. However, in the case of black pigments a type of primitive trade is evident. It is worth mentioning here that our findings are in good agreement with previous XRD and mineralogical studies, proving the use of the local manganese deposits from Iacobeni as black pigments sources for the Cucuteni ceramics in this area of Moldova.

EU COST G8 'Non-destructive analysis and museum testing' action - for funding one of the authors (Roxana Bugoi) Short Term Scientific Mission at DL, UK. EU - Research Infrastructure Action under the FP6 'Structuring the European Research Area' Programme (through the Integrated Infrastructure Initiative 'Integrating Activity on Synchrotron and Free Electron Laser Science') - for the financial support provided for the beam-times at MAX-lab, Sweden. Dr. Yngve Cerenius and the staff of beam-line I711, MAX-lab, Sweden. The staff of beam-line 14.1 of SRS, DL, UK. 


\section{REFERENCES}

CERENIUS Y., STÅHL K., SVENSSON L. A., URSBY T., OSKARSSON Å., ALBERTSSON J., LILJAS A. 2000. The crystallography beamline I711 at MAXII. Journal of Synchrotron Radiation 7: 203-208.

DUMITRESCU V. 1985. Prehistoric Art in Romania. Meridiane Publishing House. (in Romanian)

ELLIS L. 1980. Analysis of Cucuteni-Tripolye and Kurgan pottery and the implications for ceramic technology. Journal for Indo-European studies, vol. 8 (1-2): 211-230.

GÂŢĂG. 2000. A Technological Survey of the Pottery. In Marinescu Bâlcu S. and Bolomey A. (eds.), Drăgușeni. A Cucutenian Community. Archeologia Romanica II series. Editura Enciclopedică. Wasmuth Verlag. Bucureşti, Tübingen: 111-131.

MARINESCU-BÂLCU M. and BOLOMEY A. 2000. Drăgusseni. A Cucutenian Community. Archeologia Romanica II series. Editura Enciclopedică. Wasmuth Verlag. Bucureşti, Tübingen.

NICULESCU G., COLTOS C., POPOVICI D. 1982. Determinarea pigmentilor utilizati la decorarea ceramicii cucute- niene. Cercetări de Restaurare și Conservare 2: 205206 (in Romanian).

STÅHL K. 2000. The Huber G670 imaging-plate Guinier camera tested on beamline I711 at the MAXII synchrotron. Journal of Apllied Crystallography 33: 394-396.

STOS-GALE Z., ROOK E. 1981. Analysis of Pigments Used for Decorations of Neolithic Pottery from Bilcze Zlote, Ukraine. British Museum - Occasional paper, no. 19: 155161.

TANG C.C., MACLEAN E. J., ROBERTS M. A., CLARKE D.T., PRAG A. J. N. W., PANTOS E. 2001. The study of Attic black gloss sherds using Synchrotron X-Ray Diffraction. Journal of Archaeological Science 2: 1015-1024.

UDA M., SASSA S., YOSHIMURA S., KONDO J., NAKAMURA M., BAN Y., ADACHI H. 2000. Yellow, red and blue pigments from ancient Egyptian palace painted walls. Nuclear Instruments and Methods in Physics Research B 161163: $758-761$. 